\title{
Imaginative immersion in the Cistercian Cloister
}

\begin{abstract}
This article uses analytical concepts from cognitive science to explore and deepen our understanding of how medieval monastics imagined themselves as characters within biblical narratives. It argues that Cistercian monks and in particular Bernard of Clairvaux - used techniques of imaginative immersion to enter and blend themselves into biblical viewpoints and events, thereby engaging the monks in epistemically and personally transformative experiences. The article concludes that this served to build community and to enculture monks and converts. Specifically, the article offers a close reading of two of Bernard's liturgical sermons, Sermon Two for Palm Sunday and Sermon Two on the Resurrection, to show how his sermons 1) traverse time and space and 2) blend viewpoints. Examples are also taken from texts by John Cassian, Augustine, Gregory the Great, and William of St Thierry.
\end{abstract}

\section{Introduction}

An essential, yet elusive feature in Bernard of Clairvaux's writing is the profound instability of time, space, and identity. Like the liturgy itself, Bernard's sermons transcended time and space and projected the participants (or the audience/reader) into biblical roles and events. In this article, I argue that the monks used techniques of imaginative immersion to enter and blend themselves into biblical viewpoints, thereby engaging the monks in epistemically and personally transformative experiences. I conclude that their immersion into biblical characters and events served to build community, to enculture monks and converts, and at the same time to sever their ties to their past experiences and extramural memoires: in short, to transform them into Cistercian monks.

In this regard, it is significant that Cistercians recruited only adults. Early Cistercian ordinances omitted the common Benedictine practice of taking child oblates, i.e., youngsters offered by their parents to be reared in the monastery, who had constituted the majority of Western nuns and monks until the eleventh century. ${ }^{1}$ Cistercians, then, were adult converts, with extra-mural experiences, who had abandoned families and careers to 'turn' to God (the root metaphor of 'conversion', con-versio, a term which at this time indicated entry into a monastic order). Often recruits entered the monastery in the middle or even late in life, leaving behind secular or ecclesiastical careers, families, and emotional and social experiences

\footnotetext{
${ }^{1}$ An early statute set the minimum age of Cistercian novices at fifteen, which was raised to eighteen around the middle of the twelfth century. See France 2013, 84. On child oblates, see Cochelin 2011, 64.
} 
and bonds. In other words, Cistercian monks were men with a past and with identities entangled in that past. Cistercians, then, required acculturation. But how, exactly, was this acculturation supposed to take place? How were Cistercian monks to let go of their old selves and acquire a new self?

In this article, I explore how Bernard of Clairvaux's liturgical sermons for Palm Sunday (Palm 2) and for the Resurrection (Res 2) catapulted the monks into biblical roles and viewpoints, in ways that aimed at profoundly shifting their perspectives. Palm 2 is among the few extant sermons by Bernard where the references to liturgy is explicit. In Res 2, these references are more tacit, but nevertheless crucial - just as, I believe, is the case with all Bernard's sermons. Above all, Res 2 provides a striking case of a re-enactment of a biblical scene, where Bernard and his monks 'enter into' the text that is being commented. The two sermons are chosen for their relevance to the liturgy as well as for the rich possibilities they offer an interrogation into perspective-taking.

The present analyses, while relevant for medieval Christian reading, praying, and interpreting more generally, still appertain specifically to that extraordinary space which was the twelfth-century Cistercian cloister. ${ }^{2}$ The Cistercians participated in a highly specialized culture of reading, writing, and praying. That culture was based on the transmissions and shared interpretations of texts. In this sense, the Cistercians epitomized Brian Stock's conception of a "textual community", where "[t]he outside world was looked upon as a universe beyond the revelatory text; it represented a lower level of literacy and by implication of spirituality". ${ }^{3}$ By participating in these texts and partaking in their spiritual meaning, the Cistercians established their self-awareness and sense of superiority.

When twelfth-century Cistercians imagined themselves as characters in sacred narrative, they built and expanded on patristic and monastic models. As we shall see, auctoritates such as John Cassian and Gregory the Great offered Bernard and the Cistercians fundamental principles for experiential and affective readings based on techniques of meditation and sacred reading (lectio divina) as well as the hermeneutical level of tropology (or the 'moral' reading of Scripture), which underpinned and sanctioned internalization of biblical texts. Yet, even while clearly rooted in tradition, the Cistercians also signalled a change in emphasis in Christian spirituality, an affective and psychological intensification. ${ }^{4}$ Scholars have remarked on the Cistercians' keen sense of uniqueness, their spiritual elitism, and their self-involved exegesis and emotional engagement with biblical texts. ${ }^{5}$ Henri de Lubac's beautiful (if somewhat reserved) characterization of the Cistercian monastery as a "hothouse" of spiritual elitism, a "suspension of time within an oasis", foregrounds precisely the change in emphasis which I just referred to: "Bernard treats Scripture with a new liberty", Lubac muses, "he does not

\footnotetext{
${ }^{2}$ There were devotional practices of reading, praying, and interpreting with a high degree of self-involvement also outside a Cistercian framework. On medieval devotees (not Cistercians) 'entering into' images and psalms, see Palazzo 2016, 37-45 and Fulton Brown 2012; on medieval monks embodying the Bible and 'making themselves into biblical figures' to educate the laity, see Cochelin 2011.

${ }^{3}$ Stock 1983, 90 .

${ }^{4}$ See, e.g., McGinn 1990, 193-223 and Leclercq 1979; on Cistercians as both innovators and traditionalists, there is an abundant literature, landmark studies are Newman 1996 and Bruun (ed.) 2013.

${ }^{5}$ See Pranger 2007; Engh 2014; and Leclercq 1982a.
} 
properly speaking explicate the Scripture: he applies it; he does not clarify it. [...] He pulls the texts from their context. He appropriates them". ${ }^{6}$

The monks' imagination, breaching boundaries of time, space, and identity, was hermeneutically and textually grounded. But imaginative immersion in the Cistercian cloister was also connected to monastic practice - to liturgy and processions - and embedded in material and physical surroundings. Iris Shagrir emphasizes the inherent instability of time and space in the liturgical environment:

Studies on the experience of the faithful in churches argue that the vagueness of the sense of time and space was created by a deliberate and controlled combination of elements, including the manipulation of natural and artificial light, melodies and lyrics, movements and gestures of the celebrants, garments, and odours (incense). All these ingredients invoke illusion and render impossible the normal perception of time and space, and create an internal reality in the church. $^{7}$

All Christian liturgy operated in this way, not just the Cistercian. However, Cistercian liturgy and architecture did have some distinct features. First, the Cistercians were liturgical 'minimalists'. They rejected the elaborate liturgical practices of contemporary religious orders, in particular of the Benedictine monks at Cluny, seeking to impose a simpler liturgy that was faithful to the Rule of Benedict by greatly reducing the number of hymns as well as processions and feasts. ${ }^{8}$ Second, the Cistercians banned wall painting, historiated capitals and initials, and other figural ornamentation from their churches, cloisters, and manuscripts. ${ }^{9}$ Yet, although wary of colourful and figurative decorations in their cloisters, the Cistercians revelled in creating striking and powerful images to help them in their meditation and memory-making of sacred reading. Mary Carruthers has called this 'painting pictures in the mind'. Bernard of Clairvaux himself was a master in mental painting, and his sermons loaded with luscious mental images. Precisely because Cistercian monks should continually work on constructing their own mental images to fill the unadorned, uncoloured spaces of the cloister and oratory, they should not rely on or be distracted by images created by painters or sculptors. "Lay people and clerics", Mary Carruthers observes, "may need such props and aids, but not Cistercian monks". ${ }^{11}$

Bernard, then, took upon himself the extraordinary task of producing a liturgical language that would allow for the audience/reader's participation in a spiritual reality, without the aid of 'outer' sensory stimulation. The cognitively controlled environment of the Cistercian cloister - with its bare walls and uncarved capitals, and with its perduring silence - offered exceptional possibilities for multimodal engagement with biblical images and narratives. ${ }^{12}$

\footnotetext{
${ }^{6}$ De Lubac 2000, 150-152.

${ }^{7}$ Shagrir 2010, 70 .

${ }^{8}$ Waddell 1982.

${ }^{9}$ See Pranger 2003, 47; Pranger 1994, 215-232; Reilley 2013.

${ }^{10}$ For nuanced discussions of Cistercian 'iconoclasm' and Bernard's critique of Cluny's excess in visual representation in the Apologia, see Carruthers 1998, 84-87, Astell 2006, 64.

${ }^{11}$ Carruthers 1998, 84.

${ }^{12} \mathrm{Cf}$. Sandra Blakely's discussion of Mithraic caves in this volume.
} 
I speak of this process as 'imaginative immersion'. With the term 'imaginative immersion' I intend projections across time and space (as in Palm 2) as well as appropriations of identity, that is, the adoption of biblical voices (as in Res 2).

The Merriam-Webster Dictionary defines the term 'immersion' as a) baptism by complete submersion of the person in water, and b) absorbing involvement. I use the term in the latter, metaphoric sense (as indicated by the qualifier 'imaginative') where it indicates an experience of total involvement, which has frequently been applied to representation, fiction, or simulation. Of late, the term 'immersion' has become associated with virtual reality (VR) to describe a perception of being physically present in a non-physical world, based on the user's multimodal engagement with images, sound or other sensory stimuli that provide an engrossing total environment. Although the medieval liturgy was never intended to entertain (and judging by the many references to taedium and distractedness in monastic literature, in many cases it evidently didn't, either), it did operate on the assumption that sensory stimulation may create a sense of presence of a 'non-physical' world. Similarly, Bernard of Clairvaux's sermons, while fundamentally, almost puritanically, 'mental', did nevertheless aim at something like a total immersion into an otherwise inaccessible spiritual dimension.

This study of imaginative immersion builds on Rachel Fulton Brown's expositions of empathetic immersion and experience in medieval prayer and on Jean Leclercq's notion of monastic 'biblical imagination', which allowed the monks "to picture, to 'make present', to see beings with all the details provided by the texts: the colors and dimensions of things, the clothing, bearing, and actions of the people". ${ }^{13}$ This study also draws on Mary Carruthers' work on imaginative representations and mental images in monastic rhetoric. ${ }^{14}$ Above all, I am indebted to Brian Stock's recent argument about the strong connection between sacred reading (lectio divina) and concepts of imagination (Lat. imaginatio, Gr. phantasia) from classical Roman rhetoric, brought together by early Christian and monastic writers (Augustine, John Cassian, and Benedict of Nursia). ${ }^{15}$

My interrogation into imaginative immersion develops and seeks to further advance these magisterial studies of devotional reading, praying, and preaching by applying analytical concepts from cognitive science and philosophy of mind. My primary claim is that we need to examine more carefully the ways in which Bernard (and other monastic writers) sought to project his audience (or reader) into biblical roles and events - not only why, but how. Exactly how did practices of preaching and reading create an immersion into sacred events, characters, and narrative? What textual and linguistic cues did he use in order to trigger such participation? Related to this is a second and related cluster of questions, more speculative: from what we know about cognitive processes of learning and simulation, what can we infer as to the implications of all this? On what grounds can we assume that the monks really did have a transformative experience by blending and immersing themselves into sacred narrative?

In the discussions of the two sermons and of pre-existing models of immersion (principally tropology and the 'psalmic I' of liturgical and monastic prayer), I employ the analytical terms 'deictic displacement' and 'blended viewpoint', arguing that the monks built viewpoint and multimodal engagement by mental operations of 'blending' and 'mapping' (more on

\footnotetext{
${ }^{13}$ Leclercq 1983, 75; Fulton Brown 2018.

${ }^{14}$ Esp. Carruthers 1998.

${ }^{15}$ Stock 2017.
} 
these terms shortly), by which they entered and blended themselves into biblical viewpoints and events. In the final discussions, I address the question of what we can say about how this may have affected the monks, drawing on concepts of simulation and transformative experience to shed new light on how the Cistercians may have transformed their ways of thinking, feeling, and knowing through imaginative immersion.

Current cognitive work on viewpoint and multimodality draws heavily on the established and more general theory of cognition offered by Gilles Fauconnier and Mark Turner, referred to as blending theory or conceptual integration. Blending theory explains that the mind creates new mental structures from the input of two or more mental frames, which are selectively drawn upon ('mapped') and combined in the blend, with the result that new meanings not present in the original input spaces emerge. ${ }^{16}$ The more specific research on 'blended' viewpoint and deictic displacements developed by Mark Turner, Eve Sweetser, and others, which I shall be employing here, basically proposes that we do the same with different viewpoints.

Viewpoint can be expressed linguistically and gesturally, and serves to create a spatial framework orienting interlocutors. ${ }^{17}$ "Viewpoint permeates human cognition and communication - predictably", writes Eve Sweetser, "since we never have experience of the world except as a viewpoint-equipped embodied self among other viewpointed embodied selves". ${ }^{18}$ Visual and literary representations always carry an implicit point of view and focus for the audience. As we watch, hear, or read, we respond to usually unnoticed prompts to move our viewpoint and our focus. ${ }^{19}$ Viewpoint can be expressed by deictic markers (also called indexicals) such as 'I', 'you', 'now', and 'here': words that could mean many different things in different situations, depending on the viewpoint of the person who says them. A blended viewpoint is, for example, when a letter writer states, "I have before me your letter, and you have before you my response". In the blend, writer and reader are present together and jointly attending to the letter. ${ }^{20}$ Such mental processes are pervasive and commonplace in everyday human cognition and communication, but also underlie spectacular cultural expressions like poetry and liturgy. We blend when we think, read, and communicate, because that is how human minds work.

Viewpoint structure, significantly, is not just linguistic. Since humans produce, communicate, and recognize complex meaning not just verbally, but also visually and auditively (by gesture, by tone of voice, by shifting perspective or 'zooming' in on something, etc.), blended viewpoints and deictic displacements form part of a repertoire of multimodal constructions, as when a news anchor looks deep into the camera and says to the television viewers, "It's good to have you here". But who is 'you' and where is 'here'? It is a testimony to the human ability to build blends and viewpoint that the utterance does not collapse into utter nonsense. $^{21}$

Viewpoint blends help to understand better the force of the liturgy in shaping the identities of monastic communities. The medieval liturgy systematically blended viewpoints. When the 'I' or the 'we' of a psalm verse was sung by the monks or nuns, their viewpoint was blended

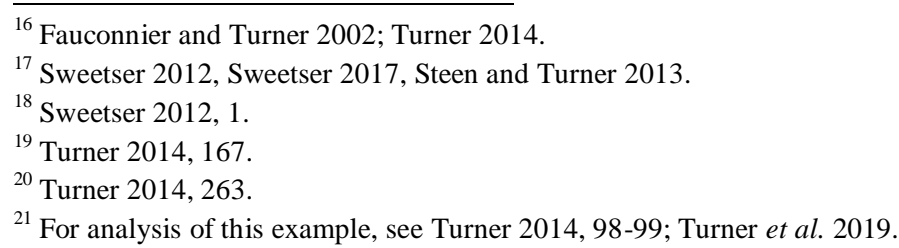


with that of the biblical figures, for instance that of the people of Israel, thus vesting them in the garb of God's chosen people. ${ }^{22}$

The implicit association between new digital technologies and the medieval monastery alluded to in the title of this essay is playful (one wonders who would be more aghast at the comparison, the monk or the gamer), but also gestures towards some assumptions that inform this article's analytical and theoretical approach. While apparently (and factually) worlds apart, medieval and modern human beings share the same embodied perception and cognitive structures. This means that cognitive research, for instance into advertising or gaming, might deepen the medievalist's understanding of monastic engagement with texts, images, and artifacts (the 'how' question). And vice versa, it means that our material and analyses are relevant for theory-building in cognitive science, too. This article, then, addresses both medieval scholars and cognitive scientists in the hope of contributing to further the ongoing, fruitful dialogue between the humanities and cognitive science. ${ }^{23}$

\section{Traversing time and space. Deictic displacements}

Bernard's collection of liturgical sermons contains a temporal cycle (the high feasts of the year) and a sanctoral cycle (feast days of saints and Marian feasts), as well as some sermons for occasions which strictly speaking were not part of the liturgical year. ${ }^{24}$ In this collection the individual sermons are clearly situated within a liturgical timeframe, each with distinct references to specific feasts as well as more indirect allusions to liturgical readings and responsories. However, these sermons were not intended for liturgical use, as Wim Verbaal has shown, because they simply did not fit into the strict and abbreviated Cistercian liturgy, nor does the collection conform to the prescriptions of the Cistercian customaries. Instead, the sermon collection was likely intended as lectio divina: continuous meditative and ruminating readings that aimed at giving the reader a deeper understanding and engagement with the divine office. ${ }^{25}$

The concept of time that underlies the sermon collection is complex, patterned on both linear and cyclical structures. ${ }^{26}$ As a whole, the collection moves according to a linear development. Beginning with the theme of expectancy and birth (the sermons for Advent), it ends with the theme of victory over death and eternal bliss (the funerary sermon for Herbert at Clairvaux). ${ }^{27}$ Concurrently, just like the liturgical year itself, the sermon collection signals a circular, repetitive concept of time, accompanying the reader throughout the intertwined temporal and sanctoral cycles of the year, year after year. As they accommodate both registers narrative progression and cyclical repetition - the sermons become dramatic, yet ritualized and almost timeless. Wim Verbaal refers thus to the atemporality of Bernard's monastery:

\footnotetext{
${ }^{22}$ See also John Romano's essay in the current volume.

${ }^{23}$ On this, see Engh and Turner 2019.

${ }^{24}$ For studies of structure and textual transmission of the collection, see Leclercq 1966a and 1966b, 209 and 211-222; Verbaal 2007, esp. xvii-xix.

${ }^{25}$ Verbaal 2013, vii; Verbaal, 2007, xxi-xxii. Bernard's collection in its final edition consists of 128 sermons for 43 occasions, more than twice as many as were permitted by Ecclesiastica officia, although Verbaal notes that the sermons were perhaps too long and complex to make them entirely suitable for lectio divina.

${ }^{26}$ Verbaal, 2013, viii; Bruun 2004, 67.

${ }^{27}$ Verbaal, 2007, xxiv.
} 
Monastic life offers a certain image of eternity by the silence reigning in a Cistercian community, by the regular, almost daily return of words and gestures that ritualize everyday life. Monastic reality tends to become atemporal, not timeless, nor eternal, but something of a no-time, in which every day is the memory of all days and at the same time the image of all days to come. $^{28}$

Verbaal's evocative description captures elegantly the profound instability of time, space, and identity in Bernard's writing. ${ }^{29}$ Verbaal's insight may be expanded through a close reading, attentive to deictic markers and deictic displacements, of Sermon Two for Palm Sunday (Palm 2) in Bernard's sermon collection. ${ }^{30}$ Bernard begins the sermon by establishing the liturgical frame of the feast of Palm Sunday:

We must speak briefly today [hodie] because of lack of time. The procession we are about to celebrate serves us in many ways, but also prevents us from talking further. Today [hodie] we are going to celebrate [celebraturi] the procession, and soon afterward we will hear [audituri] the passion. What is the meaning of this strange conjoining, and what did our fathers have in mind when they added the passion to the procession? The procession is rightly represented today [repraesentatur hodie] because it took place today [facta est hodie], but why was the passion that took place on Friday added? Rightly were the procession and the passion conjoined, so that we may learn to trust in none of the happiness of this world, knowing that the end of joy is grief [Prov 14:13]. ${ }^{31}$

The sermon opens to the celebration of a procession which, announces Bernard, is to be followed by a reading of the Passion. This 'strange conjoining' (mirabilis coniunctio), as he terms it, was a stable feature in the liturgy of Palm Sunday by the twelfth century, a result of the fusion between the Gallican rite, which commemorated the triumphal entry of Jesus into Jerusalem, and the Roman rite, which included the Gospel readings from the Passion. ${ }^{32}$

The procession and the readings are about to be celebrated (celebraturi) and heard (audituri), signalling the imminent sensory mobilization of movement and hearing. Bernard thus evokes the monks' multimodal engagement with key narratives in the life of Christ which were experienced verbally, visually, kinaesthetically, and auditively in the liturgy of Palm Sunday. He speaks directly to a 'we' and 'us', creating a literary and fictive audience of monks (since it is unlikely that the sermon was preached, at least in its current form, but was edited and distributed as a literary text for use in private and collective readings). In other words, he creates an implied reader, which I shall call the 'audience/reader', a Cistercian

\footnotetext{
${ }^{28}$ Verbaal, 2003, 235; see also Pranger 2003, 50.

${ }^{29}$ Linked to Pranger's term 'artificiality', see Pranger 18-38; also Engh 2014, 263-324.

${ }^{30}$ The sermon is one of three sermons on Palm Sunday. It has, to the best of my knowledge, never been analyzed, but Bruun 2004 offers a lucid analysis of Palm 1, with many relevant points for Palm 2.

${ }^{31}$ Palm 2.1, SBOp, 5, 46 (I modify here and in the following the trans. by Edmonds 2013, 103): "Necesse est ut loquamur hodie brevius propter angustiam temporis. Multa quidem nobis ministrat processio, quam celebraturi sumus, sed eadem impedit ne dicere plura possimus. Celebraturi sumus hodie processionem, et paulo post audituri passionem. Quid sibi vult mirabilis ista coniunctio, aut quid cogitaverunt Patres nostri, passionem addentes processioni? Nam processio quidem merito repraesentatur hodie, quae facta est hodie; passio vero cur addita est, quam sexta feria constat esse secutam? Optime utique processioni passio coniuncta est, ut discamus in nulla laetitia huius saeculi habere fiduciam, scientes quoniam EXTREMA GAUDII LUCTUS OCCUPAT".

${ }^{32}$ Harper 1991, 139-40; Martimort et al. (eds) 1983, 70-71, 75.
} 
monk or community who is engaged in sacred reading either individually or collectively, and who is invited as participant into Bernard's spiritual spectacle.

Foregrounded in the opening are the conflicting emotions of joy and grief - contained in the assonant terms processionem ('procession') and passionem ('passion'). These affectively charged oppositions are extended into the following sections, woven together in a string of biblical intertexts and responsories, which conjoins adversity, mourning, weeping, and pain (partaking in the passion) with thanksgiving, feasting, and prosperity (partaking in the procession). ${ }^{33}$ The joy and triumph of the procession is contained in the defeat and grief of the passion, and vice versa, implying, as Verbaal points out, that "each liturgical event includes every other one". ${ }^{34}$

In the brief opening phrases of the sermon, Bernard repeats 'today' [hodie] no less than four times. ${ }^{35}$ 'Today' is a deictic marker of time, which means that we need additional, contextual information to understand it fully (similarly to 'now', 'then', 'soon', etc.). When the liturgy solemnly proclaimed hodie, it signalled in a specific way the blending between the here-and-now of 'the time of the Church' and the salvific presence of 'the time of Christ'. ${ }^{36}$ In the cited opening passage, the procession, 'represented today' (repraesentatur hodie) by the celebrating monks, bridges the two temporal tiers. However, the fourth and final pronunciation of hodie signals a deictic displacement of time: the procession is 'represented today' because it 'took place today'. Clearly, the latter 'today' refers to events on a different temporal plane (Christ-time) from the former (present time), prompting the audience/reader to cognitively blend the procession of Jesus into Jerusalem with the procession of monks about to take place at Clairvaux, not just analogically but temporally. The two events are not merely parallel; they have collapsed, one into the other. Grammatically, this is enacted by a clash between 'today' and the verb in perfect tense: 'it took place today' (facta est hodie). ${ }^{37}$

As the sermon unfolds, displacements in time and space become more persistent. Bernard directs the audience/reader's attention to Christ himself: "Behold [ecce] the one before whom the garments of others were spread is stripped of his own, and lots are cast for them". ${ }^{38}$ The phrase contains reference to the gospel stories of Christ's entry into Jerusalem (the people laying down their cloaks in front of him) and the crucifixion (the soldiers casting lots to divide his clothing among themselves). Again conjoined, the procession and the passion are compressed into a dense narrative, in which the distance between preceding event (the procession) and succeeding event (the passion) collapse into the single image of strewn garments. Although these events take place in the time of Christ, the passive verb forms describing the passion are given in present tense (exuitur 'is stripped', mittitur 'is cast'), heightening the sense of urgency. The mental image of a naked, scourged Christ emerges, summoned up by the visual language and the interjection ecce ('behold'). Immediately, Bernard turns his attention to this image, addressing the suffering figure of Christ directly in the second person

\footnotetext{
${ }^{33}$ Palm 2.2-4. Salient intertexts are Mt 8:12, 13:42; Is 51:3; Eccles 7:3; Rev 21:4 as in the responsory Absterget Deus.

${ }^{34}$ Verbaal 2013, viii.

${ }^{35}$ On hodie in Bernard's writing, see also Verbaal 2013, xxiv.

${ }^{36}$ Chupungco 2000, esp. xix.

${ }^{37}$ Steen and Turner 2013, 14-15, point to past tense+now-constructions, e.g., 'He now saw that'.

${ }^{38}$ Palm 2.4, SBOp, 5, 48 (Edmonds, 105): "Cui prius prosternebantur vestimenta aliena, ecce suis exuitur, et sors mittitur super ea".
} 
singular: "How bitter to you [tibi] are our sins, which need such bitterness to wash them away!"39

Here Bernard constructs a scene of classic joint attention, in which he and his audience/reader are attending together to the figure of Christ. But, of course, there is no actual meeting, no shared time and space; the scenario is in fact a scene of blended joint attention. ${ }^{40}$ All we have are constructed viewpoints: on the one hand Bernard's authorial 'I' and on the other hand an addressee, a reader who is blended with the fictive audience, that is, the 'we' and 'us' announced at the opening of the sermon, and who is 'there' with Bernard, hearing, seeing, and experiencing what Bernard is telling and showing, even if no one is actually 'there' - but for a blended addressee, with whom the reading monk(s) is prompted to blend himself. Bernard draws the implied audience/reader's attention to a third figure (Christ), who is brought into the scene as (mute) interlocutor, and whose presence has shared repercussions (i.e., salvation) for both writer and audience/reader. In the blend, the roles are interacting, the 'now' and 'here' is shared through the 'object' of joint attention, Christ.

Now Bernard, carrying his audience/reader with him, actually stages a procession - the very procession which he initially declared that prevented him from 'speaking further'. To lend ulterior emphasis to the pending procession, we should consider that the Palm Sunday procession was a unique event in a Cistercian context. Early Cistercian ordinances dramatically reduced processions with respect to the expansive practice commonly used at the large Benedictine houses. ${ }^{41}$ Along with Candlemas, Palm Sunday was one of only two processions to take place within the liturgical year cycle. The mental (re)construction of a Palm Sunday procession, then, taps directly into monastic practice and the monks' experience with that special occasion in the liturgical year.

Bernard describes the procession, emphasizing contemporaneous temporal frames: "Now [iam] as I approach [accendens] the procession, I seem to see four groups within it; perhaps they can all be found in our procession today [hodie]". ${ }^{42}$ The procession, according to the verb tenses and the deictic markers, is taking place 'here' (hic) and 'now' (iam). ${ }^{43}$ But, as it turns out, this is a quite remarkable procession, blending elements from different temporal and spatial frames. There is the procession that is being commemorated, that took place in the past: Christ's procession into Jerusalem on Palm Sunday. Then there is the immediate focus of the sermon, namely, the present, recurrent procession ritual at Clairvaux, enacted every year. And finally, there is the future procession into the 'holy city', the heavenly Jerusalem: the eschatological promise with which the sermon ends.

As the procession files past the audience/reader's inner eye, Bernard summons up four different groups or 'ranks' (ordines). The ranks are described in a non-linear fashion, with Bernard pointing first to the head of the procession, then to the coda, and lastly arriving at the processional centre itself - the figure of Christ seated on his mule. Throughout the depiction

\footnotetext{
${ }^{39}$ Palm 2.4, SBOp, 5, 48 (Edmonds, 105): "Vae tibi, amaritudo peccatorum nostrorum, propter quae solvenda, tanta amaritudo necessaria est!"

${ }^{40}$ On classic and blended joint attention, see Turner 2014, 99-100; Turner 2015, 225-229; Turner et al. 2019.

${ }^{41}$ Bell 2013, 264-265. A third procession, the Ascension, was added around mid-century, after which the number of processions gradually grew, see Bruun 2004, $71 \mathrm{n} .15$ with references.

${ }^{42}$ Palm 2.5, SBOp, 5, 48 (Edmonds, 106): "Iam vero ad processionem accedens, tamquam quattuor ordines in ea mihi videor intueri; fortassis in hac nostra processione hodie omnes poterunt inveniri".

${ }^{43}$ Palm 2.5-6.
} 
the verbs shift rapidly between past and present tense - between the temporal and spatial planes of Jerusalem and Clairvaux. ${ }^{44}$

At the head of the procession, says Bernard, are "those who preceded [imperf. praeibant] and prepared [imperf. parabant] the way: they are those who prepare [pres.: parant] the way for the Lord into your hearts" 45 At the procession's end are those who 'followed [imperf.: sequebantur] [after Christ]'. They are "those who follow [pres.: sequuntur] in a spirit of devotion and keep always in the footsteps of those who have gone before". ${ }^{46}$ Then Bernard announces the next group: "There were [imperf.: erant] also the disciples". These proceed close to Christ, neither ahead of him nor behind him, but, "like servants, keeping to his side". "They are [pres.: sunt] those who chose the better part", Bernard declares, echoing Luke 10:42. With the allusion to Mary, sister of Martha, who exemplified the contemplative life ('the better part'), he turns the disciples into figurae for monks: "those who live in cloisters only for God, who always cling to God, considering his will". ${ }^{47}$ The monks, then, are directly identified as allegorical participants in the procession.

Finally, Bernard arrives at the last group, represented by the mule: "There was also [perf. non defuit] the beast of burden on which [Christ] sat [imperf. insidebat]. It represents the hard-hearted and those who have brutish souls". ${ }^{48}$ Here again a specifically monastic and liturgical context emerges. These individuals, associated with the beast, are 'unable to sing', Bernard charges; they only 'bray'. ${ }^{49}$ The privilege of using the voice - reading, chanting, preaching, and chastising - was a primary hierarchical marker in the Benedictine community. ${ }^{50}$ Contrarily, the inarticulate braying of the mule signals this group's spiritual and social inferiority in a monastic framework. Here Bernard steps into the role of the stern, disciplining abbot: "If some such are here [hic] for whom the discipline is heavy and all things burdensome [...] I beg them to change from beasts into men [homines]". ${ }^{51}$ The incomplete humanness, or failed manliness, of these unhappy monks is upheld in the following section where the image of the beast is exchanged with an image of a sick child: "When a mother knows that her child is sick she nurtures it more, and embraces it more often [...] She nurtures [the little ones] in her bosom [gremio] until they grow stronger". ${ }^{53}$ As the beast transmutes into a

\footnotetext{
${ }^{44}$ On the 'telescoping' of Clairvaux and Jerusalem, a topos in Bernard's writing, see Bruun 2004, 73 -75.

${ }^{45}$ Palm 2.5, SBOp, 5, 48-49 (Edmonds, 106): "Praeibant enim aliqui et viam parabant: ipsi sunt qui viam parant Domino ad corda vestra".

${ }^{46}$ Palm 2.5, SBOp, 5, 49 (Edmonds, 106): "hi sunt qui propriae inscientiae conscii, devote sequuntur, et adhaerent semper vestigiis praecedentium".

${ }^{47}$ Palm 2.5, SBOp, 5, 49 (Edmonds, 106): "Erant quoque discipuli, tamquam domestici, lateri eius adhaerentes. Ipsi sunt qui partem optimam elegerunt, qui in claustro soli Deo vivunt, semper Deo adhaerentes, et eius placitum considerantes".

${ }^{48}$ Palm 2.5, SBOp, 5, 49 (Edmonds, 106): "Ipsum quoque iumentum, cui insidebat, non defuit, quod designat duros corde, et animos quodammodo bestiales".

${ }^{49}$ Palm 2.5, SBOp, 5, 49 (Edmonds, 106): "Huiusmodi namque cantare non norunt, sed male sonoros dant rugitus".

${ }^{50}$ E.g., Coon, 2011, 81.

${ }^{51}$ Palm 2.6, SBOp, 5, 49 (Edmonds, 106): "Si qui tales sunt hic, quibus gravis sit Ordo, et omnia onerosa, quos pungi frequenter oporteat et urgeri, obsecramus eos ut studeant de iumentis, si forte queant, in homines commutari".

${ }^{52}$ As Karras 2003 points out, the opposite of a man (manliness) in the middle ages was not necessarily a woman (femaleness), but could also be a child or a beast, see chaps 3-4.

${ }^{53}$ Palm 2.6, SBOp, 5, 50 (Edmonds, 107): "Nam et mater quem aegrotantem novit filium, magis fovet et saepius a mplectitur. [...] eos tamquam mater misericordiae suae gremio fovet, donec roborentur".
} 
child, the role of chastising (paternal) abbot is replaced by a more nurturing and maternal role. $^{54}$

Thus both Bernard (the abbot-mother) and the monks (the beast-child) are present and participating in the biblical narrative. This becomes even clearer as Bernard proceeds. "There are four kinds of people, then, in the Lord's procession": 'the wise and good' up front, 'the simple and good' at the back. ${ }^{55}$ In the middle near Christ, there are the contemplatives who 'cling' (adhaerent) to him, ${ }^{56}$ as well as those who 'carry him' and are 'burdened by him'. As this imaginary scene unfolds, the procession comes into view, hazily and disorderly at first, but then, gazing into the shadows of Bernard's figurative interpretation, the implied audience/reader will recognize the contours of a Palm Sunday Procession at Clairvaux. The first group, those who 'prepare the way', corresponds to the thurifer, the first to file in a Palm Sunday Procession, carrying the lighted censer. Next, at the processional centre, Christ himself is represented by the processional cross; and, accordingly, the 'beast on which Christ sits' corresponds to the cross-bearer. Close by, those who 'keep to his side' (adhaerent ipsi), who 'chose the best part', i.e., the disciple-monks, correspond to the celebrating ministers. Lastly, 'those who follow' are the rest of the congregation: the other monks and lay brothers along with guests and familiares, who, on the occasion of Palm Sunday, would exceptionally be invited to enter the choir and join in the procession in the cloister. ${ }^{57}$

In Christian liturgy, the Palm Sunday procession was nothing less than a monastic reenactment of sacred history: Christ's triumphal entry into the city of Jerusalem which was, concurrently, an anticipation of humanity's future entry into the New Jerusalem. Movement, chants, olfaction, and vision invited the participants to blend their sensory experience into the biblical narrative of Christ's life as well as into the eschatological future. The Palm Sunday procession, then, aimed at participation in the main events of the history of redemption, not just the entire Easter Week, including the Triumphal Entry and the Passion, but also the Last Judgement. ${ }^{58}$ The procession was a specific point in space and time where the biblical, liturgical, and eschatological levels of reality blended together, conflating past, present and future, heaven and earth.

Likewise, the procession in Bernard's sermon traverses boundaries of time and space. At the closing of Bernard's sermon there are no less than three diverse processions that come together: Christ's entry into Jerusalem that is being commemorated, the monastic liturgical procession that frames the sermon, and the terrestrial Church's journey through history. In the last passages of the sermon, Bernard again addresses his imaginary audience/reader directly and directs their attention to Christ, but the figure has become elusive, almost imperceptible: "But behold [ecce]," he exclaims, "they are all in the Lord's procession - but none of them can see his face!"59 Vision - visibility and invisibility - is foregrounded, but only the con-

\footnotetext{
${ }^{54}$ See Bynum 1982 and Engh 2014.

${ }^{55}$ Palm 2.7, SBOp, 5, 50 (Edmonds, 107): "Quattuor ergo sunt genera in processione Domini. Boni prudentes, et boni simplices: hi sunt qui praeeunt, et qui sequuntur".

${ }^{56}$ Adhaerere was a central term in Latin monastic theology to denote spiritual union with God; cf. 1 Cor 6.17: "Qui autem adhaeret Domino, unus spiritus est". See McGinn 1994, 70, 136, 181; Casey 1988, 201 -208.

${ }^{57}$ Bruun 2004, 71 and 76; Sternberg 2013, 179.

${ }^{58}$ Bruun 2004

${ }^{59}$ Palm 2.7, SBOp, 5, 50 (Edmonds, 107): "Sed ecce omnes sunt in processione Domini, et nemo ex ipsis faciem eius videt”.
} 
templatives, clinging to the Lord's side, manage to catch a glimpse of him, and even they only "fleetingly and not continuously, nor can they see him fully". ${ }^{60}$ Clearly, this is no longer the historical Jesus entering Jerusalem on his mule - someone accessible to the senses, who could be seen, heard, and touched. In the midst of Bernard's procession walks the God who told Moses, "no one shall see me and live [Ex 33:20]": the object of beatific vision, reserved for the afterlife. At this point, Bernard gives voice to God himself: "I shall not be seen, he says", Bernard says, "in this life [in hac vita]; no one shall see my face on this path [in hac via] and in this procession [in processione ista]". 61

The Augustinian concept of earthly life as a pilgrimage, toiling 'on the way' (in via) towards the homeland, is echoed in Bernard's 'this path' (hac via) and 'this procession' (processione ista), corresponding to 'this life' (hac vita). Bernard maps the procession onto present life using specific temporal and spatial frames: "while they are still on the way" (dum adhuc sunt in via), "while he [Moses] was alive in the world" (dum viveret in hoc mundo), "while we are alive" (dum vivimus). ${ }^{62}$ As Jean Leclercq has shown, Bernard's texts evoke a future eschatological restoration (which is anticipated but not fully realized in the monastery) by using adverbs such as interim ('for the time being'). ${ }^{63}$ In the present sermon, dum ('while') has much the same function, emphasizing the transient character of earthly life, while also indicating movement and progression towards a goal.

At the sermon's closing, the procession arrives at the gates of New Jerusalem, the heavenly city. But this is no longer just the monastic procession. Blended with the pilgrimage of present life and the peregrinating Church, this is the ultimate, triumphant entry into the eschatological, future kingdom. Pointing to 'that' (illa) future procession in contrast to 'this' (ista) present procession in the former passage, Bernard reduplicates the processions, gesturing towards the pending metamorphosis as the procession arrives at the gates of heavenly Jerusalem:

May he in his great loving-kindness grant us so to persevere in his procession while we are alive [dum vivimus], so that in that great procession [in magna illa processione], in which he is to be received by the Father with all those who belong to him, and will hand over the kingdom to God his Father, we may be worthy to enter the holy city with him who lives and reigns forever. ${ }^{64}$

From the lofty vantage point of Bernard (and his audience/reader), a spiritual scenario opens up, albeit mentally constructed, wholly imaginary. For when Bernard stages an imaginary imitation of a Palm Sunday procession in which here and now, there and then are compressed and blended, he cannot relate it to the tangible, sensory activation of liturgy, at least not directly. Nor can he rely on the support of visual images. There simply are none. Instead he

\footnotetext{
${ }^{60}$ Palm 2.7, SBOp, 5, 50 (Edmonds, 108): "Qui vero adhaerent ipsi, aliquando videre possunt, sed raptim et non continue, nec plene dum adhuc sunt in via".

${ }^{61}$ Palm 2.7, SBOp, 5, 51 (Edmonds, 108): "NON VIDEBIT ME HOMO, ET VIVET. Non videbor, inquit, in hac vita; non videbit quis faciem meam in hac via, et in processione ista".

${ }^{62}$ Palm 2.7.

${ }^{63}$ Leclercq 1962, 328-329.

${ }^{64}$ Palm 2.7, SBOp, 5, 51 (Edmonds, 108): "Ipse itaque magna pietate sua donet nobis sic in eius processione perseverare dum vivimus, ut in magna illa processione, qua cum suis omnibus a Patre suscipiendus est, et traditurus regnum Deo et Patri, sanctam civitatem cum ipso ingredi mereamur qui vivit et regnat per omnia saecula saeculorum”.
} 
involves the audience by having them actively build mental space blends: connecting the recurrent liturgical procession, with which the monks had first-hand experience, to Christ's entry into Jerusalem as well as to redeemed humanity's entry into New Jerusalem. The sermon does not invent these connections - they were already there - but it allows for an affective and cognitive participation in both the biblical past and the eschatological future through imaginative immersion.

Bernard's sermon invited the monks into a spiritual spectacle as witnesses, onlookers, and participants in sacred narrative, giving them access to a non-physical, spiritual dimension that was otherwise inaccessible and intangible. Through deictic displacements (such as 'here', 'there', 'this', 'that' 'today', 'while') the monks traversed time and space.

\section{Creeping inside the text. Blended viewpoint and the psalmic ' $I$ '}

Deictic markers of space and time were not the only means by which Bernard and his monks immersed into sacred narrative. Another, closely related way was to 'adopt' the voice and viewpoint of a biblical character. As mentioned in the introduction, viewpoint can be expressed by deictic markers such as 'I', 'you', 'now', and 'here': words that could mean many different things in different situations, depending on the viewpoint of the person who says them. 'Blended' viewpoint is when we take structure from two different viewpoints and blend them, for example creating an identification between the 'I' (the deictic centre) and another person's viewpoint. In a recent analysis, Eve Sweetser identifies deictic displacement as a viewpoint blend:

[A] clear example is that in English, the correct response to the invitation Can you come to my party? is Sure, I'd love to come, not Sure, I'd love to go. The invitation accepter might later say to a third party I'm going to Sandy's party on Friday, and would be unlikely to say come in this context. The acceptance utterance thus participated in the inviter's deictic structure, displacing the accepter's deictic center to the inviter's. [...] The crucial point here is that our everyday construal of personal viewpoint is a blend. It's a blend which is so common that it is hard to notice it. We normally experience our own bodies simultaneously as loci of our conscious Selves or Egos, agents of our speech and action, spatial sources of our fields of perceptual access and manual reach, interfaces of social interaction, and more. But [...] we also naturally create such models for other individuals around us - aided, very possibly, by our mirror neurons, which respond to other humans' grasping actions (for example) as well as to our own. ${ }^{65}$

Cognitive linguistics draws attention to basic mental operations that underlie human communication - in everyday language as well as in advertising, rhetoric, and literature. ${ }^{66}$ Poets and advertisers, Sweetser observes, are "craftsmen [who] know how to build blends, and to draw viewers into the desired viewpoint". 67 In Palm 2 discussed above, the deictic displacements called for a blend of viewpoints, which Bernard stage-managed from the point of view of a narrator but where the events experienced are to be construed from the point of view of a past (or future) self or consciousness. Turner and Steen describe the cognitive operation at work:

\footnotetext{
${ }^{65}$ Sweetser 2012, 9-10.

${ }^{66}$ See, e.g., Sweetser 2017; Turner 2002; Fauconnier and Turner 2002.

${ }^{67}$ Sweetser 2017, 66.
} 
"The blended viewpoint takes on elements of different perspectives and compresses a time relation. The mental space of the narrator's condition is still the mental space from which the narrated space is accessed and built up, but the experiential perspective comes from inside the narrated events". ${ }^{6}$

As a matter of fact, medievalists and biblical scholars have long called attention to a striking instance of blended viewpoint; they just speak about it differently. They call it 'the psalmic "I"'. ${ }^{69}$ The 'I' that speaks in the psalms, according to Augustine, is both the voice of Christ and the voice of humans: "it is our voice and not our voice, it is the voice of the Spirit of God and not his voice". ${ }^{70}$ The psalmic 'I' of monastic prayer and liturgy served as a hermeneutical space, a placeholder so to speak, for the reader to position him- or herself in order to fully take in the meaning and the first-person emotion claims of the psalms: "to inhabit them", in the words of Rachel Fulton Brown, "to make them his (or her) own", to achieve an integration of the psalter and the self. "One becomes a sort of living concordance", as Leclercq pointed out, "a living library, in the sense that the latter term implies the Bible". ${ }^{2}$

The tropological sense of hermeneutics - i.e., the 'moral' level of meaning of Scripture had always retained an experiential perspective in biblical reading, creating, as Stefka Eriksen points out in this volume, a space for the development of the interior man where the cognitive transformation of the self could take place. Gregory the Great (r. 590-604), for instance, described tropology as a hermeneutical principle of appropriation and interiorization of the biblical text: "For we should transform that which we read within ourselves, so that when the mind is moved by hearing, our way of life puts into practice that which it has heard". ${ }^{73}$ This hermeneutical principle of internalizing and appropriating biblical texts - not just committing them to memory but making them one's own - is expressed in an extraordinary passage in John Cassian's Conferences (c.426), here in the context of liturgy and prayer. Through the mouthpiece of the desert father Isaac, Cassian urges the aspiring Christian to imagine himself as the author of the psalms as he prays and reads:

[He] should take in to himself all the affections [adfectus] of the psalms and begin to sing them as if they were the compositions not of the prophet [i.e., David], but rather his own private prayer uttered amid the deepest compunction of the heart, as if they were directed at himself and recognize that their words were not only fulfilled formerly by or in the person of the prophet, but that they are fulfilled and carried out daily in his own case. Then indeed the scriptures lie ever more clearly open to us [...] Seized by the identical affections [affectus] in which the psalm was composed or sung we become, as it were, its author [...] Its words stir memories within us, memories of the daily attacks which we have endured and are enduring, the cost of our negligence or the profits of our zeal [...] For all these affections [adfectus] we find expressed in the psalms so that by seeing as in a very clear mirror we understand it better,

\footnotetext{
${ }^{68}$ Steen and Turner 2013, 15.

${ }^{69}$ E.g. Mays 1991; McNamer 2010; Nightingale 2015; Doriani 1989.

${ }^{70}$ Augustine, Enarrationes in Psalmos, 26.2.1 (PL 36:199, my trans.): "et nostram esse vocem, et nostram non esse; et Spiritus Dei esse vocem, et ipsius non esse". The principle is repeatedly expressed, e.g. Enarrationes in Psalmos 4.1 (PL 36:78): "aut verba Dominici hominis post resurrectionem exspectare debemus, aut hominis in Ecclesia credentis et sperantis in eum”. See also Nightingale 2015, esp. 60-62.

${ }^{71}$ Fulton Brown 2012, 75.

${ }^{72}$ Leclercq 1982a, 77.

${ }^{73}$ Gregory the Great, Moralia in Iob, 1.24.33 (PL 75:542C, my trans.): "In nobismetipsis namque debemus transformare quod legimus; ut cum per auditum se animus excitat, ad operandum quod audierit vita concurrat".
} 
and so instructed by our feelings as our teachers we lay hold of it as something not merely heard but actually seen, and, as if it were not committed to memory, but implanted in the very nature of things, we are affected from the very bottom of our heart, so that we get at its meaning not by reading the text but by experience anticipating it. ${ }^{74}$

This is not primarily a didactic scheme, it's a cognitive shift. It's about affective and empathetic imagination, stepping into another viewpoint. ${ }^{75}$ It's about integrating the Bible into the self. The psalms must be read and memorized so that the experiences out of which they were written are made the personal experiences of the reader. ${ }^{76}$ Through the Rule of Benedict, Cassian's views on the role of experiential reading were systematized and diffused in monastic reading and praying in the West. ${ }^{77}$ Hence William of St Thierry, a 'black' Benedictine turned Cistercian monk and contemporary and friend of Bernard, urges in the Golden Epistle (c.1145):

You will never enter Paul's meaning until you have imbibed his spirit by constant application to reading him and by giving yourself to constant meditation. And you will never understand David until you assume the affections of the Psalms in your own experience. ${ }^{78}$

Bernard of Clairvaux was ingrained in this rich tradition in monastic writing. Undeniably an expert cognitive 'craftsman', he built viewpoints and blends in his sermons in order to imagine and project himself and his monastic audience into biblical figures and events. Bernard was quite explicit about this aim, as we find in his famous manifesto at the opening of Sermon 3 in the Sermons on the Song of Songs:

Today we will read in the book of experience [libro experientiae]. Now turn to yourselves, each one of you must search your own awareness for what will be discussed. I wish to discov-

\footnotetext{
${ }^{74}$ John Cassian, Conférences, 2, Conlatio 10.11 (SC, 54, 92-93; trans. Gibson, NPNF, 335, my modifications): “omnes quoque psalmorum adfectus in se recipiens ita incipiet decantare, ut eos non tamquam a propheta conpositos, sed uelut a se editos quasi orationem propriam profunda cordis conpunctione depromat uel certe ad suam personam aestimet eos fuisse directos, eorumque sententias non tunc tantummodo per prophetam aut in propheta fuisse completas, sed in se cotidie geri inplerique cognoscat. Tunc enim scripturae divinae nobis clarius perpatescunt [...] Eundem namque recipientes cordis affectum quo quisque decantatus vel conscriptus est psalmus, uelut auctores eius facti [...] quid in nobis gestum sit uel cotidianis geratur incursibus superueniente eorum meditatione quodammodo recordemur, et quid nobis uel neglegentia nostra pepererit uel diligentia conquisierit [...] Omnes namque hos adfectus in Psalmis inuenimus expressos, ut ea quae incurrerint, uelut in speculo purissimo peruidentes efficacius agnoscamus et ita magistris adfectibus eruditi non ut audita, sed tamquam perspecta palpemus, nec tamquam memoriae conmendata, sed uelut ipsi rerum naturae insita de interno cordis parturiamus adfectu, ut eorum sensus non textu lectionis, sed experientia praecedente penetremus".

${ }^{75}$ Cf. Pinker 2011, 174, discussing the eighteenth-century novel: "Reading is a technology for perspective-taking. When someone else's thoughts are in your head, you are observing the world from that person's vantage point. [...] Stepping into someone else's vantage point reminds you that the other fellow [sic] has a first-person, present-tense, ongoing stream of consciousness that is very much like your own but not the same as your own. It's not a big leap to suppose that the habits of reading other people's words could put one in the habit of entering other people's minds, including their pleasures and pains".

${ }^{76}$ Coleman 1992, 176.

${ }^{77}$ On reading and meditation practices in BR and Cassian's influence on these, see Stock 2017, $31-40$.

${ }^{78}$ William of St Thierry, Golden Epistle, 31.121 (PL 184:327D, attr. to Guido of Chartreuse; trans. Berkeley, 51, my modifications): "Nunquam ingredieris in sensum Pauli donec usu bonae intentionis in lectione ejus, et studio assiduae meditationis, spiritum ejus imbiberis. Nunquam intelliges David, donec ipsa experientia ipsos Psalmorum affectus indueris".
} 
er if any one of you has had the privilege of saying [ex sententia]: Let him kiss me with the kiss of his mouth. [Song 1:1] For there are not many to whom it is given to utter these words in true affection $\left[\right.$ ex affectu.$^{79}$

The emphasis on tropology in Cistercian exegesis is well-known, epitomized in Bernard's readings of the bride as the soul in the Sermons on the Song of Songs. ${ }^{80}$ This way of reading and approaching Scripture is intense, emotional, interior, and concerned with the contemplative's intimate relationship with God. Above all, it is concerned with experience. Tropology, especially in its monastic and Cistercian garb, signals an interpretation which aims at furthering contemplative progress rather than outlining moral prescripts.

Yet Bernard's exegesis passes even beyond tropology. Bernard not only commented biblical texts and explained their spiritual meaning, he deliberately re-enacted them - not, perhaps, so much in the sense of 'acting' as in the sense of 'activating'. ${ }^{81}$ In his sermons Bernard gave voice to biblical characters, weaving together biblical verses to enact a narrative or dialogue. The audience, too, became a part of the ongoing drama, not merely listening to the words but participating directly in a densely symbolical and artificial world of spiritual meaning. Carrying his audience with him, Bernard 'entered' into the text he was preaching about in order to integrate the text in the self, to re-enact the text, and, ultimately, to embody and inhabit the text. The boundary between the preacher and his subject-matter are blurred to the extent that he 'creeps' into the biblical scenes, as M.B. Pranger observed, making himself and his audience part of what is going on inside the text. ${ }^{82}$

A remarkable example is found at the end of the sermon quoted above, Sermon 3 of the Sermons on the Song of Songs. Here Bernard returns to the kiss of the opening verse of the Song of Songs, but approaches it in a more immediate and intensely emotional way, addressing first his fellow monks and then Christ the bridegroom himself:

And then, finally, after many prayers and tears, we might - perhaps - dare to raise our eyes to his glorious mouth, not merely to look upon him, but even - I say it with fear and trembling to kiss him. [...] And now what remains, O good Lord, except that suffused in the fullness of your light, in the fervour of my spirit, let me approach your mouth, your kiss; fill me with the joy of your presence! ${ }^{83}$

Note that Bernard rather abruptly shifts his reading from first person plural to first person singular. The audience/reader is jolted into realizing that Bernard is actually re-enacting the first verse in the first chapter of the Song of Songs with which he opened the sermon, having

\footnotetext{
${ }^{79}$ Bernard of Clairvaux, Scc 3.1; SBOp, 1, 14 (trans. Walsh, 16, my modifications): "Hodie legimus in libro experientiae. Convertimini ad vos ipsos, et attendat unusquisque conscientiam suam super his quae dicenda sunt. Explorare velim, si cui umquam vestrum ex sententia dicere datum sit: OSCULETUR ME OSCULO ORIS SUI. Non est enim cuiusvis hominum ex affectu hoc dicere".

${ }^{80}$ See Engh 2014; Matter 1990, chap. 5; Lubac 2000, chap. 9.

${ }^{81}$ For emphases on performativity, see Pranger 2003, 47; Verbaal 2003, 241; Engh 2014, 6-8. Caveat by Palazzo, 2014, 12-13, 131: not acting but activating.

${ }^{82}$ Pranger 2007, 37

${ }^{83}$ Scc 3.5-6, SBOp, 1, 17 (Walsh, 20): "Postremo cum ista multis precibus et lacrimis obtinemus, tunc demum audemus forsitan ad ipsum os gloriae caput attollere, pavens et tremens dico, non solum speculandum, sed etiam osculandum [...] Et nunc quid restat, o bone Domine, nisi ut iam in plenitudine lucis, in fervore spiritus, ad oris quoque osculum dignanter admittens, adimpleas me laetitia cum vultu tuo?"
} 
adopted the viewpoint (if not the words) of the bride: "Let him kiss me with the kiss of his mouth" (Song 1:1). He has gone full circle: his didactic proclamation at the sermon's opening is fulfilled and realized in his passionate plea for the bridegroom's kiss at the sermon's closing. In other words, Bernard has just crept into the opening verse of the Song of Songs.

Bernard's performative exegesis in the Sermons of the Song of Songs consists of systematically blending his viewpoint with that of the bride of the Song. He appropriates the bride's desire, making it his own. Throughout the Sermons, phrases from the Song delivered in Bernard's voice move him to the deictic center whereby - narratively and grammatically - the bride's ego in the biblical text becomes his own ' $\mathrm{I}$ ' ${ }^{84}$ Bernard inhabits the text of the Song in full cognitive and emotional participation. At the same time, he invites his audience/reader into that space - a (female) space to be occupied by a (male) signifier. ${ }^{85}$

\section{Being there. The resurrection of the self}

Bernard's Sermon Two on the Resurrection (Res 2) involves radical viewpoint blends whereby the monks not only witness, but actively enter into biblical events and characters. This sermon features a re-staging of a biblical scene (based primarily on Matt 28:1-6 and Mark 16:1-6): the women who run to the tomb of Jesus at early dawn only to find it empty - except for an angel sitting on top of the tombstone. ${ }^{86}$ The sermon invites the monks (i.e., the audience/reader) to appropriate the viewpoint and the voice of these women. Thus they are to identify not only with biblical figures, but specifically with female ones. Scholars have pointed to the complex layers of meaning evoked by associating males with female traits and stances in Cistercian and medieval writing: it could function as a marker of physicality and humanity over against (male) divinity; as an inversion of values, emphasizing female weakness and humility; and as an expression of monastic renunciation and 'superior lowliness'. ${ }^{87}$ In the case of Res 2, I believe that the blended viewpoint, and the ensuing gender blending, has a very specific, albeit tacit reference: Mary Magdalene. Although the four gospel stories seem incongruent as to how many and which women were present at the tomb on Easter Sunday, all four versions include Mary Magdalene. ${ }^{88}$ Through her identification (or conflation) with the aforementioned Mary, sister of Martha, who typified contemplation, Mary Magdalene was associated with monastic conversion and monastic life. ${ }^{89}$ More specifically, the rise of the cult of Mary Magdalene coincided and intertwined with the spread of the Cistercians in Burgundy in the twelfth century. ${ }^{90}$ For the Cistercians, with their practice of adult-only recruitment, Mary Magdalene offered a liturgical model for monastic life, which perfectly ex-

\footnotetext{
${ }^{84}$ See Engh 2014, 9 and 247-261.

${ }^{85}$ Haperin, 295; Engh 2014, 397.

${ }^{86}$ Pranger 2007, 39-40, and 1994, 303-313, has given an insightful analysis of the present sermon upon which I build and expand.

${ }^{87}$ Bynum 1986; Engh 2014; Newman 2003; Krahmer 2000.

${ }^{88}$ Mark (16:1) has three women: Mary Magdalene, Mary mother of James, Salome (sometimes known in later traditions as Mary Salome): hence the 'three Marys'. Matthew (28:1) has two: Mary Magdalene accompanied by another Mary. Luke (24:10) has an unspecified number, including Mary Magdalene, Joanna, Mary mother of James, as well as 'other women'. In John (20:1) Mary Magdalene came by herself. See Shagrir 2010, 62. Bernard explicitly refers to the women as three.

${ }^{89}$ On this, see Leclercq $1982 \mathrm{~b}, 92-105$.

${ }^{90}$ See Scarcez 2014, 52.
} 
pressed the Cistercian emphasis on deep-felt conversion and repentance of past sins. Indeed, themes of 'turning' to or away from God (con-vertere and re-vertere) reverberate throughout the sermon Res 2 .

The finding of Christ's empty tomb is the liturgical climax of Easter: the announcement of the resurrection (by the angel). This biblical scene became the basis for popular liturgical plays known as Visitatio sepulchri: liturgical enactments of the dialogue between the women and the angel at the empty tomb. ${ }^{91}$ The so-called Quem quaeritis trope (from the angel's words to the women: 'Whom do you seek?') was added to the liturgy in the Carolingian period. At the end of the tenth and the beginning of the eleventh century, the trope began to appear in liturgical texts accompanied by rubrics which instructed the celebrating clerics what to say, where to stand, when to raise their voices, what to wear and so forth. ${ }^{92}$ Iris Shagrir notes that: "The performance of the trope as a dramatic play should be seen as a meaningful change in religious mentality, as it may reflect a desire to impress upon the community an emotional experience, and to reinforce the theological idea of resurrection in an immediate and bonding manner at a climactic moment of the liturgical cycle". ${ }^{93}$

In much the same way, Bernard's sermon on the resurrection gave dramatic representation to a theological re-working of the idea of the resurrection through an emotional experience which, as we shall see in the final discussion, aimed to build community. Bernard's sermon is not just a remembering of a biblical event; it is a tropological re-staging which tells of the death and resurrection of a fallen soul - an imaginative immersion into the restoration of the self. The essential structure of the sermon is simple, namely, that of death exchanged for life (resurrection), although its blends are highly complex.

The tropological approach is announced at the opening of the sermon, where Bernard begins to blend Christ's empty tomb with a person - a believer in whom Christ is dead: "As long as faith lives in us, so does Christ. But if our faith has died, then Christ is in some measure dead in us". ${ }^{44}$ Having established the faithless soul as a tomb, Bernard carefully builds another blend on top of this: to live without faith is to die. "There are some, alas," huffs Bernard "who start with the spirit but afterwards end with the flesh. We know then that the spirit of life is now no longer in them". ${ }^{95}$

Following the Pauline oppositions of life and death, spirit and flesh (Rom 8:13), Bernard inverts these oppositions to describe lapsed monastics, converts who revert to fleshly and worldly desires: "So if to live according to the flesh is death, we no doubt mourn as if they are dead those who live according to according to the flesh, those whose life we rejoiced in as long as they mortified their flesh in the spirit". ${ }^{66}$ Here the traditional monastic theme of being 'dead to the world' is radicalized. Inside the monastery, death (of the flesh) is life, and con-

\footnotetext{
${ }^{91}$ Discussed by Nils Holger Petersen in this volume. See also Cochelin 2011, 71.

${ }^{92}$ Shagrir 2010, 64.

${ }^{93}$ Ibid.

${ }^{94}$ Res 2.1, SBOp, 5, 95 (Edmonds, 159, my modifications in this and the following): "tamdiu Christum in nobis vivere, quamdiu vivit fides. At postquam fides nostra mortua est, quodammodo Christus mortuus est in nobis".

${ }^{95}$ Res 2.1, SBOp, 5, 95 (Edmonds, 159-160): "Sed nonnulli, cum spiritu coeperint, heu! carne postea consummantur. Scimus autem quia jam tunc non permaneat in eis spiritus vitae".

${ }^{96}$ Res 2.2, SBOp, 5, 95 (Edmonds, 160): "Denique si sapere secundum carnem mors est, non dubium quin illi, quos vivere laetabamur, quamdiu facta carnis spiritu mortificabant, secundum carnem viventes plangendi sint tamquam mortui".
} 
versely life (of the flesh) is death. A monk in whose soul faith has died, then, is himself utterly dead because Christ is dead in him: "Who is deader than this?" asks Bernard. ${ }^{97}$

So the resurrection story turns out to be about none other than this lost soul which is as dead as dead can be. Here the familiar process of the liturgy - where Christ is born and raised from the dead over and over again - is disrupted, left uncertain, and urgent. Escalating the immediacy and intimacy of his rhetoric, Bernard begins to involve his reader/audience more directly: "Behold, Christ is in the tomb, and faith is dead in the soul. What shall we do?" 98 The blend between tomb and soul - as containers of death (in sepulcro ... in animo) - might at first glance appear to be a mere pretext for the tropological reading that follows. Only in the sermon's dramatized closing passage will this blend between a tomb and a person take on full meaning.

For the time being, Bernard goes on to establish yet another blend: an identity relation between the women at the tomb (the 'holy women') and the monastic 'we'. The point of identification are the spices. At Bernard's question - 'what shall we do?' - the women enter: "What did the holy women do [...]? They brought spices, so that they might go and anoint Jesus [Mark 16:1]". ${ }^{99}$ The three women who brought their spices trigger the tripartite schemes that dominate the ensuing, lengthy middle section of the sermon. Here Bernard allegorizes the spices which the women brought to anoint Christ's body. The spices represent mind, tongue, and hand. ${ }^{100}$ These correspond to prayer, preaching, and example (Res 2.3: animi oratione, verbi exhortatione, exempli exhibitione) which must be accompanied by their three respective virtues: affectionate compassion (compassionis affectum), zeal for uprightness (rectitudinis zelum), and spirit of discretion (discretionis spiritum) (Res 2.4). Bernard's communal Benedictine ideals and monastic ascesis of the mind are reflected in his insistence on the need to put aside the self, to extinguish the self-will (voluntas propria). The three spices, i.e. the virtues, "must be bought with the money of self-will [...] so that what was private might be common". ${ }^{101}$ Again underlying monastic inversions emerge: as the self empties itself of that which is its 'own' (propria), it is restored to life.

Bernard instructs his audience/reader on how to feel, speak, and act, constructing more tripartite divisions within the established tripartite division. But all this, we are soon to find out, is but a preparation for the spectacular grand finale of the sermon.

Here Bernard brings together all the traditional props and characters from the biblical story (Mk 16:1-6 and Mt 28:1-6): the women who come with spices to anoint Christ's dead body, the angel who announces to them that Christ has risen, the tombstone which is rolled back from the opening of the grave on which the angel sits, and the mystery of the empty tomb. The lengthy allegorizations of the spices are at an end - it is time to act:

Approach him, then, him in whom faith has died, with those spices. Truly, if we consider what a great thing it is to restore [suscitare] someone in this state to life - how difficult it is to reach his heart [cor eius] closed by stony [lapidea] obstinacy and shamelessness - I think that we

\footnotetext{
${ }^{97}$ Res 2.2, SBOp, 5, 95 (Edmonds, 160): "Quis magis mortuu eo?"

${ }^{98}$ Res 2.3, SBOp, 5, 95 (Edmonds, 160): "Ecce igitur Christus in sepulcro, fides mortua est in animo. Quid faciemus ei?"

${ }^{99}$ Res 2.3, SBOp, 5, 95 (Edmonds, 160): "Quid fecerunt sanctae mulieres [...]? EMERUNT AROMATA, UT VENIENTES UNGERENT JESUM".

${ }^{100}$ Res 2.3, SBOp, 5, 95 (Edmonds, 160-161): "Emant proinde aromata sua tres mulieres, mens, lingua, manus".

${ }^{101}$ Res 2.8, SBOp, 5, 98 (Edmonds, 163): "Tria ergo aromata mentis nummo propriae voluntatis emenda sunt [...] ut communis fiat quae propria fuit".
} 
too must say: Who will roll away the stone [lapidem] for us from the entrance to the tomb? $[\mathrm{Mk} 16: 3]^{102}$

The key to this sermon, as Pranger's analysis made clear, is to pay careful attention to the shifting identities of the various dramatic characters and speakers in the sermon's closing narrative. The passage just cited gives a direct quote from Mark 16:3: 'who will roll away the stone for us, etc.?' In the gospel story, these are the women speaking, but in this text the 'we' (nos) and 'us' (nobis) indicate Bernard and the monks, and by extension the audience/reader. So they - that is, the monastic 'we' - are blended with the three women at the tomb; they speak in the biblical women's voice. Concurrently, there is also the mysterious sinner whose identity is still hidden and whose heart is an empty tomb, closed off by a tombstone: inaccessible, inapproachable. Indeed, the lapsed monk's 'stony' obstinacy and shamelessness is the tombstone.

The passage continues:

But while we tremble and fear to approach, resisting so great a miracle, it sometimes happens that the divine ear, compassionate as always, hears the preparation of our heart [cordis nostri] and, with a mighty voice, raises up again he who was dead. ${ }^{103}$

Almost unnoticeably, the stony heart just became 'our hearts'. The whole scene has suddenly become even more precarious, as distinctions between the nameless, faceless 'him' (the lapsed monk) and the 'we' of Bernard and his audience/reader collapse. But the most spectacular blend is still to come, with the entry of the angel:

And, behold [ecce], the angel of the Lord, with a certain merriment in his expression, appears to us as at the opening of the tomb. His is a kind of brightness as an indication of resurrection, suggesting that his looks have clearly changed. He offers us access to his heart [cor suum]; even more, he calls us, rolling back the very stone of his obstinacy [obstinationis suae revolvens lapidem], and, sitting on it, so as to show us, after faith has been raised from the dead, the shrouds in which it had been wrapped. And, as he reveals all the previous agitations of his heart [in corde suo] he also confesses how he had buried himself within, and admitting to his own tepidity and negligence he says: Come and see the place where the Lord was laid to rest [Mt 28:6]. ${ }^{104}$

\footnotetext{
${ }^{102}$ Res 2.12, SBOp, 5, 102 (Edmonds, 166): “Cum his igitur aromatibus accede ad eum in quo fides mortua est. Verum si consideremus quam magnum sit ad nos suscitare eum qui eiusmodi est, quam difficile sit vel accedere ad cor eius, quod lapidea quaedam obstinatio et impudentia clausit, puto quod dicere habeamus et nos: QUIS REVOLVET NOBIS LAPIDEM AB OSTIO MONUMENTI?"

${ }^{103}$ Res 2.12, SBOp, 5, 102 (Edmonds, 166-167): “Attamen dum sic trepidi veremur accedere, cunctantes ad tam grande miraculum, fit nonnumquam ut, solita pietate praeparationem cordis nostri audiat auris divina, et ad vocem virtutis eius resurgat qui erat mortuus".

${ }^{104}$ Res 2.12, SBOp, 5, 102 (Edmonds, 167): "Et ecce Angelus Domini, hilaritas quaedam in vultu illius, tamquam in ostio monumenti nobis apparet, et fulgor quidam index resurrectionis, ut aperte videatur facies illius immutata, accessum praebens nobis ad cor suum, immo et advocans, ipsumque obstinationis suae revolvens lapidem, et sedens super eum, ita ut, suscitata fide ipsa, etiam linteamina, quibus obvoluta fuerat, ipse demonstret. Dumque omnia quae in corde suo prius actitabantur aperit, et confitetur quomodo seipsum sepelierat intus, ipsam tepiditatem et negligentiam suam prodens: Venite, inquit, et videte locum ubi positus erat Dominus (Matth. XXVIII, 6)”.
} 
At the centre of everything that has been going on was the question of the identity of the mysterious figure in whom Christ had died. Now it is revealed. Remarkably, it is no other than the angel. Pranger notes: "Unlikely though it may seem, it is the angel himself who contains all the other persons and events surrounding the grave, or, more precisely, it is the stone he is sitting on". ${ }^{105}$ I would add that it is the heart, variously identified as a generic self, a tomb, a stone, an angel, that contains all the elements in the story: human, angelic, and divine nature; death and resurrection.

This final scene offers a strikingly multimodal engagement with the narrative and with the characters, which far exceeds conventional analogies. The audience/reader's visual imagination is mobilized with the interjection ecce ('behold') and thereafter reinforced in a series of mental pictures, almost like a multi-panel sequence, that are concluded verbally with the angel's announcement of the resurrection to the women (from Mt 28:6). Through these mental 'panels' Bernard creates the effect of 'zooming' in on the scene, gradually moving his audience/reader closer up, revealing a completely transformed gospel story, but one that is still recognizable as such. ${ }^{106}$

In the first of the mental panels, the angel comes into view at the opening of the tomb. The viewpoint is that of the approaching women. In the second, we (the audience/reader, whose viewpoint is blended with the women-monks) zoom in on the angel himself - specifically, on his heart, identified as the tomb. In the third, we are given a close-up of the angel's heart, to which he now gives us entry by rolling away the tombstone that had closed it off. In the fourth mental panel, we glimpse the contents inside, empty except for the limp funerary shrouds. In the fifth, another revelation: the deceased - or rather the resurrected - who is inside the tomb, and whose identity has never really been in question until now, turns out to be not (or at least not only) Christ, but the sinner himself: the self who had buried himself inside himself (seipsum sepelierat intus). When, finally, the angel speaks, one is no longer sure whose viewpoint this really is. Is it the monks'? the women's? the angel's? the resurrected self's? Are we inside the tomb? Or outside looking in?

Throughout this process of imaginative immersion, the viewpoint blends require quite some mental acrobatics, because, as Pranger observed, in this tropological hide-and-seek all characters and events are contained in the empty tomb, the angel, and the stone he is sitting on: the heart of the monastic everyman. All is held together by the container metaphor at the base of the blends (the tomb, the heart), and the stone that sealed it.

The angel re-tells the resurrection story from the point of view of the monastic subject in whose heart Christ is resurrected, and who thus is resurrected himself. From atop the stone which separated us from him, the angel gestures towards the empty shroud and unveils the real story behind the central and final event of Christian faith. In one hazy moment we glimpse, beyond the dissolved boundaries between events, persons, time, and space, the mystery of the resurrection, ever present and ever re-performed by the monks.

\footnotetext{
${ }^{105}$ Pranger 2007, 8.

106 Steen and Turner 2013, 15, note that "it is easy to 'zoom' in visual imagination. [...] Zooming seems to be a very common and easy manipulation in imagination. Perhaps imagination works this way because we do have the actual experience of an image in the visual field getting 'larger' as we move toward it or 'smaller' as we move away from it, and we can of course do time-scaling in imagination because of blending, so zooming in imagination is available as a product of blending over experience, but not projecting to the blend the movement of the viewer".
} 
In this sermon, Bernard pulls the resurrection of Christ from its context to offer it - as an immersive experience - to his monks. He appropriates it.

\section{Transformative and immersive experiences. The first person perspective}

What can we say about how imaginative immersion affected the monks? Can we assume that the monks really did have a transformative experience by blending and immersing themselves into sacred narrative? In a recent study, philosopher Laurie Paul argues that transformative experiences are precisely those that change a person's point of view:

Her knowledge of what something is like, and thus her subjective point of view, changes. With this new experience, she gains new abilities to cognitively entertain certain contents, she learns to understand things in a new way. ${ }^{107}$

To have a new and different kind of experience entails an epistemic transformation: acquiring knowledge of what something is like. Epistemically transformative experiences may be of a sensory nature, Paul explains, such as smelling, tasting, and seeing (significantly, modes of experience which were at the heart of the liturgy), ${ }^{108}$ but they may also arise from "nonsensory phenomenological features of experiences, especially rich, developed experiences that embed a range of mental states, including beliefs, emotions, and desires". ${ }^{109}$ Some such experiences, she notes, are not only epistemically transformative but also personally transformative, changing one's understanding of oneself, one's identity - creating a new self. ${ }^{110}$ Paul calls attention to the cognitive power of the 'first personal perspective': epistemically and personally transformative experiences require direct experience, a first-person perspective. ${ }^{111}$ In the words of David Lewis:

If you want to know what some new and different experience is like, you can learn it by going out and really having that experience. You can't learn it by being told about the experience, however thorough your lessons may be. ${ }^{112}$

Lewis concludes: "What's essential is that when we learn what an experience is like by having it, we gain abilities to remember, imagine and recognize". ${ }^{113}$ For our concerns this is the crux of the issue. With the monastic 'we' or 'I' of Bernard's sermons, just like with the psalmic 'I' of the divine office and sacred reading, the experiential perspective comes from inside the narrated events. For Bernard not only observes the mental scenes that he conjures up for his monks, he lives in them, with a fully sensory, emotional, and rational experience. ${ }^{114}$

\footnotetext{
${ }^{107}$ Paul 2014, 10-11.

${ }^{108}$ Paul gives examples of epistemically transformative experience: to see the colour red or taste the fruit durian for the first time.

${ }^{109}$ Paul 2014, 12.

${ }^{110}$ Paul 2014, 16-17. Paul's examples of personally transformative experiences include: to get a new job, to have a baby, and religious conversion.

${ }^{111}$ Questions of the first-person perspective ('indexical') and the intrinsic nature of experience are contested subjects in philosophy of mind, see McCoy, Paul, and Ullman 2019.

${ }^{112}$ Lewis 1999, 262. Cited in Paul 2014, 10.

${ }^{113}$ Lewis 1999, 290. Cited in Paul 2014, 10.

${ }^{114}$ Also Carruthers 2010, 194 (on Peter of Celle).
} 
But we may ask: are Bernard and the monks (with Lewis and Paul) really having the experience?

Bernard clearly orchestrated a projection of his audience/reader into the minds or firstperson perspective of other selves: in the phrasing of cognitive scientists, he is "running a simulation". ${ }^{115}$ Perhaps the monks' experience is comparable to that of an empathetic reader of narrative fiction, who engages in the emotions and motivations of fictional characters? Or, more intriguing still, perhaps Bernard models the same kind of cognitive shift as contemporary digital games, where instead of watching the characters the user observes the game world from their point of view? Gaming and reading are cognitively related technologies for building viewpoints. Notably, virtual reality (VR) generates a first-person viewpoint to maximize the immersive user experience. ${ }^{116}$ Both in the case of VR and in the case of a reader of, say, a nineteenth-century epistolary novel who gets to step inside another person's vantage point and experience her pleasure and pains, immersion depends on the human ability to blend viewpoint and to understand other agents and indeed themselves through a process of simulation. ${ }^{117}$

Cognitive operations of immersion and simulation, moreover, seem to have repercussions beyond reading or gaming. It may also be essential to cultural learning, to building communities. In a forthcoming contribution to the ongoing debates on Theory of Mind, ${ }^{118}$ Samuel Veissiere and others argue that "human agents learn the shared habits, norms, and expectations of their culture through immersive participation in patterned cultural practices that selectively pattern attention and behaviour". ${ }^{119}$ They call this process "Thinking through Other Minds'. Immersive participation in cultural practices, they claim, afford epistemic resources (called cultural affordances); in short, people are encultured through inhabiting other people's minds.

When Cistercian monks, every one of them adult converts, engaged in imaginative immersion, as characters within biblical narratives and even as protagonists in the resurrection, they created a possible (or virtual) self. Through repeated practice the possible self was available for deployment in monastic acculturation. What is at stake here, in cognitive terms, is that engaging in a 'virtual' or fantasy world triggers the kind of transfer learning that is characteristic of pretend play and simulation: you learn at the level of narrative structure. ${ }^{120}$ The power of simulation is that the pretend self is also a possible self.

\footnotetext{
${ }^{115}$ E.g., Hogan 2003, 148.

${ }^{116}$ Research into digital games show that the first-person viewpoint is the most suitable condition to induce a high sense of presence and that users are more immersed in the game play when viewing the game world through the eyes of the character in first person perspective than playing in the third person point of view; see Slater et al. 2010; and Denisova and Cairns, 2015.

${ }^{117}$ From different perspectives Pinker 2011 and Zunshine 2006 emphasize self-engagement and empathetic reading in the eighteenth- and nineteenth-century novel.

118 The human ability to ascribe and make inferences regarding other people's mental states, intentions, and feelings is usually referred to as Theory of Mind (TOM). TOM is variously called also 'folk psychology', 'mind reading', or 'mentalizing'. Several scholars associated with the fields of the philosophy of mind, cognitive science, and theoretical neuroscience argue that TOM plays a significant role in human cognition. For a recent discussion, see McCoy, Paul, and Ullman (2019).

${ }^{119}$ Veissiere et al. 2019, 1.

${ }^{120}$ Steen and Owens 2001.
} 


\section{Conclusion. Building community}

Applying analytical concepts from cognitive science, which draw attention to viewpoint structures and cognitive processes of immersion and simulation, I have argued that multimodal constructions of blended viewpoint afforded an experiential perspective that comes from inside the narrated events and that allowed participation in those events. Like John Cassian, who urged the praying and reading Christian to imagine himself (or herself) as the author of the psalms, Bernard of Clairvaux attempted to create a first-person immersive experience: a medieval VR, if you will.

When Bernard and his monks crept inside biblical narratives they inhabited other minds in ways that were epistemically and personally transformative. Their multimodal engagement with texts, sustained and supplemented in their daily lives by readings, chants, and visual cues, helped them to pattern their emotions and perceptions, to bestow new knowledge and increased understanding, and to create new forms of meaning for their existence. ${ }^{121}$ Bernard, then, was making sure that the monks were having an experience by which they gained abilities to remember, to imagine, and to recognize. But these were to be specifically spiritual experiences. "Bernard's monk seems to have trained himself to an habitual loss of self", proffers Janet Coleman, "distinguished by a purged memory and a capacity for remembering only the universal experiences of the sensual delights of Scripture". ${ }^{122}$

Experience, as Bernard's sermon on the resurrection suggests (and as Coleman argues), is not just personal and private. Like emotions and memories, experiences can also be literary and communal. ${ }^{123}$ Indeed, even the psalmic 'I' was ultimately a collective rather than an individual utterance. ${ }^{124}$ Bernard's sermons, along with monastic practices of reading and praying, offered an identity that was, on the one hand, collective rather than just individual and, on the other hand, biblical and Christological rather than just personal. ${ }^{125}$ While I agree with Coleman's emphasis on 'universal experiences' (rather than just individual), I have a rather different interpretation regarding the 'loss' of the self. The instability of viewpoint means that it is still the monk's perspective while at the same time the perspective of the biblical figures. Bernard and the monks were aiming not so much at a rupture with their past selves as at a transformation and, ultimately, a resurrection of the self: that Christ be restored in the self by extinguishing the self-will (Res 2).

The new self, collective and Christological, was central to building community and acculturating the monks. The individual 'I' became communal, and biblically grounded. As Verbaal points out in this volume, the goal of the liturgy, and arguably of monastic life itself, was to attain unity of the faithful with the divine Spouse: an ongoing transformation of the community of individuals into the body of the Christ. Monastic conversion, i.e., the entry into monastic life, was a kind of 're-set button': a new life, patterned on the 'new man' (homo novus), Christ, where vivid biblical images filled up the monks' minds, replacing their private memories with scriptural reminiscences and converting individual identities into communal

\footnotetext{
${ }^{121}$ Here I paraphrase from Lisa Zunshine's discussion of TOM and literature, 2006, 164.

${ }^{122}$ Coleman, 186

${ }^{123}$ On the emphasis on the creation of the community and on the group rather than the individual in Benedict's Rule, see Stock 2017, 46, cf. Rosenwein 2010, on emotional communities.

${ }^{124}$ Nightingale 2015, 60 .

${ }^{125}$ Cf. Mays, 1991, 90.
} 
ones - so that 'what was private might be common' (Res 2.8). ${ }^{126}$ Cistercian writing and liturgy carried a distinct emphasis on transformation, often signalled by recurrent Pauline themes connected with the term formare ('to form') and its cognates uniformare ('to make uniform'), reformare ('to re-form'), conformare ('to con-form'), and transformare ('to transform'). The Cistercian cloister acculturated monks to reform and transform the community to conform to Christ and to the pristine, original divine likeness of creation. "127 "At my Clairvaux, among the numerous novices, often both noble and learned," Nicholas, Bernard's secretary, declared, "the new man is born in the newness of life". ${ }^{128}$

Bernard's sermons aimed to change the monks and their ways of thinking, feeling and knowing in an ongoing process of conversion and Christomimetic transformation. His concern was to impress on his community an epistemically and personally transformative experience. In this sense, imaginative immersion is potentially a tool for transformation. This, of course, is the most speculative part of my argument. Did the monks really change? It lies beyond the scope of our research to prove that the monks definitely did change, but we can show how Bernard and his monks modelled and triggered imaginative immersion, and we do know that these cognitive processes are available for cultural learning and acculturation. Cognitive science can tell us that when the monks immersed, simulated, and blended, they gained cultural affordances and participated in cultural practices that selectively patterned attention and behaviour. The Cistercians exploited mental operations that all human minds share; but they used them in ways that were highly complex and distilled, that required rigid mental discipline and exercise. ${ }^{129}$

Line Cecilie Engh

University of Oslo

l.c.engh@ifikk.uio.no

\footnotetext{
${ }^{126}$ See Coleman 1992, 176.

${ }^{127}$ On this, see also McGinn 1990; and Waddell 1990.

${ }^{128}$ Nicholas of Clairvaux, Ep. 35 (PL 196:1627A): "in mea Clarevalle [...] ubi frequens numerositas tam nobilium quam litteratorum novum hominem in novitate vitae parturient”. Cited also in Lubac 2000, 151.

${ }^{129}$ I would like to thank Stefka Eriksen, Francis F. Steen, Mark Turner, and the anonymous reader for their valuable comments and feedback on the present study, notwithstanding, any inaccuracies and mistakes are my own.
} 


\section{BIBLIOGRAPHY}

\section{Sources}

Augustine, Enarrationes in Psalmos; Patrologiae cursus completus: series latina, ed. by J.-P. Migne, Paris, 1841-66 [=PL] 36, 67-1028.

Bernard of Clairvaux, "In ramis palmarum. Sermo secundus [=Palm 2]", in J. Leclercq et al. (eds.), Sancti Bernardi Opera [=SBOp], vol. 5, Roma: Editiones cistercienses, 1968, 46-51; trans. I. Edmonds, Bernard of Clairvaux: Sermons for Lent and Easter Season (Cistercian Fathers Series 52), Collegeville, MI, 2013, 103-108.

Bernard of Clairvaux, "In resurrectione. Sermo sedundus [=Res 2]", in J. Leclercq et al. (eds.), SBOp, 5, Roma: Editiones cistercienses, 1968, 95-102; trans. I. Edmonds, Bernard of Clairvaux: Sermons for Lent and Easter Season (Cistercian Fathers Series, 52), Collegeville, MI 2013, 159-167.

Bernard of Clairvaux, "Sermones super Cantica canticorum [=Scc]", in J. Leclercq et al. (eds.), SBOp, vol 1, Roma: Editiones cistercienses, 1957; trans. K. Walsh, Benard of Clairvaux: Sermons on the Song of Songs (Cistercian Fathers Series 4), Kalamazoo, MI, 1971.

Gregory the Great, Moralia in Iob, 1.24.33; PL 75, 509-1162.

John Cassian, Conférences / Conlationes, 8-17, vol. 2, ed. E Pichery (Sources Chrétiennes [=SC], 54), Paris: Éditions du cerf, 1958; trans. E.C.S. Gibson, The Conferences of John Cassian (Nicene and Post-Nicene Fathers [=NPNF], Series 2, 11), New York 1894.

Nicholas of Clairvaux, Epistola 35; PL 196, 16261631.

William of St Thierry, Epistula ad fratres de MonteDei / The Golden Epistle; PL 184: 307-364 [attr. to Guido of Chartreuse]; trans T. Berkeley, The Golden Epistle: A Letter to the Brethren at Mont Dieu (The Works of William of St Thierry, 4; Cistercian Fathers Series, 12), Spencer; MA 1971.

Studies

Astell A. 2006: Eating Beauty: The Eucharist and the Spiritual Arts in the Middle Ages, Ithaca.

Bell N. 2013: "Liturgy", in M.B. Bruun (ed.), The Cambridge Companion to the Cistercian Order, Cambridge.

Bruun M.B. (ed) 2013: The Cambridge Companion to the Cistercian Order, Cambridge.
Bruun M.B. 2004: "Procession and Contemplation in Bernard of Clairvaux's First Sermon for Palm Sunday", in N.H. Petersen, Bruun M.B., Llwellyn J., and Østrem E., The Appearances of Medieval Rituals: The Play of Construction and Modification (Disputatio 3), Turnhout, 67-82.

Bynum C.W. 1982: "Jesus as Mother and Abbot as Mother", in C.W. Bynum, Jesus as Mother: Studies in the Spirituality of the High Middle Ages, Berkeley, 110-169.

Bynum C.W. 1986: “'And Woman His Humanity' Female Imagery in the Religious Writing of the Later Middle Ages", in C.W. Bynum, Harrell V. and Richman P. (eds.), Gender and Religion: On the Complexity of Symbols, Boston, Beacon, 257 288.

Carruthers M. 1998: The Craft of Thought: Meditation, Rhetoric, and the Making of Images, 400-1200, Cambridge.

Carruthers M. 2010: "The Concept of ductus: Or Journeying Through a Work of Art", in M. Carruthers, Rhetoric Beyond Words: Delight and Persuasion in the Arts of the Middle Ages, Cambridge, 190219.

Casey M. 1988: Athirst for God: Spiritual Desire in Bernard of Clairvaux's "Sermons on the Song of Songs" (Cistercian Studies, 77), Kalamazoo.

Chupungco A. 2000: "Liturgical Time and Space: 1. Theological premise", in A. Chupungco, Liturgical Time and Space (Handbook for Liturgical Studies, 5), Collegeville, MI, xvii-xxvi.

Cochelin I. 2011: "When Monks Were the Book", in S. Boynton and Rielly D.J. (eds.), The Practice of the Bible in the Middle Ages: Production, Reception, and Performance in Western Christianity, New York, 61-83.

Coleman J. 1992: Ancient and Medieval Memories: Studies in the Reconstruction of the Past, Cambridge.

Coon L.L. 2011: Dark Age Bodies: Gender and Monastic Practice in the Early Medieval West, Philadelphia.

Denisova A. and Cairns P. 2015: "First Person vs. Third Person Perspective in Digital Games: Do Player Preferences Affect Immersion?" in CHI '15: Proceedings of the 33rd Annual ACM Conference on Human Factors in Computing Systems. Association for Computing Machinery (ACM), 
33rd Annual CHI Conference on Human Factors in Computing Systems, 145-148 DOI: https://doi.org/10.1145/2702123.2702256.

Doriani B.M. 1989: “"Then Have I... Said with David': Anne Bradstreet's Andover Manuscript Poems and the Influence of the Psalm Tradition", Early American Literature 24, 52-69.

Engh L.C. 2014: Gendered Identities in Bernard of Clairvaux's "Sermons on the Song of Songs": Performing the Bride (Europa Sacra, 15), Turnhout.

Engh L.C. and Turner M. 2019: "Introduction: A Case Study of Symbolic Cognition”, in L.C. Engh (ed.), The Symbolism of Marriage in Early Christianity and the Latin Middle Ages: Images, Impact, Cognition, Amsterdam, 13-35.

Fauconnier G. and Turner M. 2002: The Way We Think: Conceptual Blending and the Mind's Hidden Complexities, New York.

France J. 2013: "The Cistercian Community", in M.B. Bruun (ed), The Cambridge Companion to the Cistercian Order, Cambridge, 80-86.

Fulton Brown R. 2012: "My Psalter, My Self; or How to Get a Grip on the Office According to Jan Mombaer: An Exercise in Training the Attention for Prayer", Spiritus: A Journal of Christian Spirituality 12, 75-105.

Fulton Brown R. 2018: Mary and the Art of Prayer: The Hours of the Virgin in Medieval Christian Life and Thought, New York.

Halperin D.M. 1990: "Why Is Diotima a Woman? Platonic Erōs and the Figuration of Gender", in D.M. Halperin, Winkler J.J., and Zeitlin F.I. (eds.), Before Sexuality: The Construction of Erotic Experience in the Ancient Greek World, Princeton, 257308.

Harper J. 1991: The Forms and Orders of Western Liturgy: From the Tenth to the Eighteenth Century, Oxford.

Hogan P.C. 2003: Cognitive Science, Literature, and the Arts: A Guide for Humanists, New York/London.

Karras R.M. 2003: From Boys to Men: Formations of Masculinity in Late Medieval Europe, Philadelphia.

Krahmer S.M. 2000: "The Virile Bride of Bernard of Clairvaux", ChHist 69, 304-327.

Leclercq J. 1962: "Saint Bernard écrivain”, Recueil d'études sur Saint Bernard et ses écrits, vol. 1 (Raccolta di Studi e Testi, Storia e letteratura, 92), 321-352.

Leclercq J. 1966a: "Introduction: Sermones per annum”, in J. Leclercq and H. Rochais, SBOp vol. 4, Rome: Editiones Cistercienses, 125-159.
Leclercq J. 1966b: "La tradition des sermons liturgiques de s. Bernard", in Recueil d'études sur Saint Bernard et ses écrits, vol. 2 (Raccolta di Studi e Testi, Storia e letteratura 104) Rome, 185-260.

Leclercq J. 1982a: The Love of Learning and the Desire for God: A Study of Monastic Culture, New York.

Leclercq J. 1982b: Monks on Marriage: A Twelfth Century View, New York.

Leclercq J. 1979: Monks and Love in Twelfth CenturyFrance: Psycho-Historical Essays, Oxford.

Lewis D. 1999: "What Experience Teaches", in D. Lewis, Papers in Metaphysics and Epistemology, Cambridge, 262-290.

Lubac H. de 2000: Medieval Exegesis. The Four Senses of Scripture, vol. 2, Edinburgh.

Martimort A.G. et al. (eds.) 1983: The Church at Prayer: An Introduction to the Liturgy, vol. 4: The Liturgy and Time, Collegeville, MI.

Matter E.A. 1990: The Voice of My Beloved: The Song of Songs in Western Medieval Christianity, Philadelphia.

Mays J.L. 1991: “Question of Identity: The Threefold Hermeneutic of Psalmody", The Asbury Theological Journal 46, 87-94.

McCoy J., Paul L.A., and Ullman T. 2019: "Modal Prospection", in A. Goldman and McLaughlin B. (eds.), Metaphysics and Cognitive Science, Oxford, 235-267.

McGinn B. 1990: "Freedom, Formation, and Reformation: The Anthropological Roots of Saint Bernard's Spiritual Teaching”, Analecta Cisterciensia 46, 91-114.

McGinn B. 1994: The Growth of Mysticism: From Gregory the Great to the Twelfth Century (The Presence of God: A History of Western Christian Mysticism, 2), London: SCM.

McNamer S. 2010: Affective Meditation and the Invention of Medieval Compassion, Philadelphia.

Newman M.G. 1996: The Boundaries of Charity: Cistercian Culture and Ecclesiastical Reform, 1098-1180, Stanford, CA.

Newman M.G. 2003: "Real Men and Imaginary Women: Engelhard of Langheim Considers a Woman in Disguise", Speculum 78, 1184-213.

Nightingale A. 2015: "The 'I' and 'Not I' in Augustine's Confessions", Arion 23, 55-78.

Palazzo É. 2014: L'Invention chrétienne des cinq sens dans la liturgie et l'art au Moyen Âge, Paris.

Palazzo É. 2016: Peindre c'est prier: Anthropologie de la prière chrétienne, Paris.

Paul L.A. 2014: Transformative Experience, Oxford.

Pinker S. 2011: The Better Angels of Our Nature: Why Violence Has Declined, New York. 
Pranger M.B. 1994: Bernard of Clairvaux and the Shape of Monastic Thought: Broken Dreams, Leiden.

Pranger M.B. 2003: The Artificiality of Christianity: Essays on the Poetics of Monasticism, Stanford.

Pranger M.B. 2007: "The Persona of the Preacher in Bernard of Clairvaux", Medieval Sermon Studies 51, 33-40.

Reilley D. 2013: “Art”, in M.B. Bruun (ed.), The Cambridge Companion to the Cistercian Order, Cambridge, 125-139.

Rosenwein B.H. 2010: "Problems and Methods in the History of Emotions", in Passions in Context International Journal for the History and Theory of Emotions [online journal], 1 http://www.passionsincontext.de.

Scarcez A. 2014: "The Proto-Cistercian Office for Mary Magdalene and Its Changes in the Course of the Twelfth Century", in P.V. Loewen and Waugh R. (eds.), Mary Magdalene in Medieval Culture: Conflicted Roles, New York/London: Routledge, 51-74.

Shagrir I. 2010: "The Visitatio Sepulchri in the Latin Church of the Holy Sepulchre in Jerusalem”, AlMasāq 22, 57-77.

Slater M. et al. 2010: "First Person Experience of Body Transfer in Virtual Reality", PLoS ONE, 5 DOI: https://doi.org/10.1371/journal.pone.0010564.

Steen F.F. and Turner M. 2013: "Multimodal Construction Grammar", in M. Borkent, Dancygier B. and Linnell J. (eds.), Language and the Creative Mind, Stanford, CA, 1-20.

Steen F.F. and Owens S.A. 2001: "Evolution's Pedagogy: An Adaptationist Model of Pretense and Entertainment", Journal of Cognition and Culture 1, 289-321.

Sternberg M. 2013: Cistercian Architecture and Medieval Society, Leiden/Boston.

Stock B. 1983: The Implications of Literacy: Written Language and Models of Interpretation in the Eleventh and Twelfth Centuries, Princeton.

Stock B. 2017: The Integrated Self: Augustine, the Bible, and Ancient Thought, Philadelphia.

Sweetser E. 2012: "Introduction: Viewpoint and Perspective in Language and Gesture, From the Ground Down", in B. Dancygier and Sweetser E. (eds.), Viewpoint in Language: A Multimodal Perspective, Cambridge, 1-22.

Sweetser E. 2017: "Metaphor and Metonymy in Advertising: Building Viewpoint in Multimodal Multi-Space Blends", Journal of Pragmatics 122, 6576.

Turner M. 2002: “The Cognitive Study of Art, Language, and Literature", Poetics Today 23, 9-20.

Turner M. 2014: The Origin of Ideas: Blending, Creativity, and the Human Spark, Oxford.

Turner M. 2015: "Blending in Language and Communication”, in E. Dabrowska and Divjak D. (eds.), Handbook of Cognitive Linguistics (HSK, 39), Berlin/Boston, 211-232.

Turner M. et al. 2019: "Blended Classic Joint Attention and Multimodal Deixis", Signo. Santa Cruz do Sul 44, 3-9.

Veissiere et al. 2019, "Thinking Through Other Minds: A Variational Approach to Cognition and Culture", Behavioral and Brain Sciences, Cambridge, 1-97. DOI: https://doi.org/10.1017/S0140525X19001213.

Verbaal W. 2003: "Timeless Time: Dramatical Eternity in the Monastery under Bernard of Clairvaux", in G. Jaritz and Moreno-Riano G., Time and Eternity: The Medieval Discourse (International Medieval Research 9), Turnhout, 233-250.

Verbaal W. 2007: "The Sermon Collection: Its Creation and Edition", in J. Leinenweber (ed.), Bernard of Clairvaux: Sermons for Advent and the Christmas Season (Cistercian Fathers Series 51), Collegeville, MI, xii-lix.

Verbaal W. 2013: “An Introduction to Saint Bernard's Sermons for Lent and Easter", in M.A. Scott (ed.), Bernard of Clairvaux: Sermons for Lent and the Easter Season (Cistercian Fathers Series 52), Collegeville, MI, vii-lxiii.

Waddell C. 1982: "The Reform of the Liturgy from a Renaissance Perspective", in R.L. Benson and Constable G. (eds.), Renaissance and Renewal in the Twelfth Century, Cambridge.

Waddell C. 1990: "The Glorified Christ, Present and Future: The Eschatological Dynamic of the Spiritual Life", Analecta Cisterciensia 46, 327-42.

Zunshine L. 2006: Why We Read Fiction: Theory of Mind and the Novel, Columbus. 